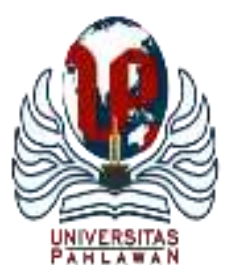

Edukatif : Jurnal Ilmu Pendidikan Volume 4 Nomor 1 Tahun 2022 Halm 289 - 297

EDUKATIF: JURNAL ILMU PENDIDIKAN

Research \& Learning in Education

https:/ledukatif.org/index.php/edukatif/index

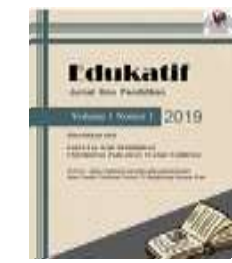

\title{
Pengembangan Bahan Bacaan Bahasa Inggris Berbasis Budaya Lokal Ende-Lio untuk Siswa Sekolah Menengah Pertama
}

\author{
Ningsih $^{1 凶}$, Yuliana M.D’K.Kara ${ }^{2}$ \\ Program Studi Pendidikan Matematika Universitas Flores ${ }^{1}$, Program Studi Sastra Inggris Universitas Flores ${ }^{2}$ \\ E-mail : ningsihverbhy@gmail.com ${ }^{1}, \underline{\text { melkar076@ gmail.com² }}{ }^{2}$
}

\begin{abstract}
Abstrak
Berdasarkan wawancara singkat dengan guru bahwa guru masih menggunakan teks bacaan yang ada di dalam buku daripada menyusun sendiri teks bacaan sesuai dengan tema dan jenis teks yang dipelajari pada pertemuan tertentu. Dari hasil wawancara singkat tersebut maka peneliti menerapkan potensi kearifan lokal dalam proses pembelajaran di kelas, terutama dalam penyajian teks bacaan sesuai dengan tema yang dipelajari. Pengembangan bahan bacaan ini diawali dengan menganalisis potensi kearifan lokal.Penelitian ini menggunakan metode Research and Development (R\&D) dengan merujuk pada model Dick and Carey dengan sedikit penyesuaian sesuai konteks penelitian. Adapun langkahlangkah pembelajarannya mencakup (1) mengidentifikasi tujuan umum pembelajaran, (2) melaksanakan analisis pengajaran, (3) mengidentifikasi tingkah laku masukan dan karakteristik siswa, (4) merumuskan tujuan performansi, (5) mengembangkan butirbutir tes acuan patokan, (6) mengembangkan strategi pengajaran, (7) mengembangkan dan memilih material pengajaran, (8) mendesain dan melaksanakan evaluasi formatif, (9) merevisi bahan pembelajaran, (10) mendesain dan melakukan evaluasi sumatif. Hasil uji validasi produk bahan bacaan bahasa Inggris berbasis kearifan lokal Ende-Lio oleh ahli materi, ahli bahasa dan media di peroleh kategori Baik dengan skor $90 \%$.
\end{abstract}

Kata Kunci: Pengembangan, Bahan Bacaan, Bahasa Inggris , Budaya Lokal, Ende-Lio

\begin{abstract}
Based on a brief interview with the teacher that the teacher still uses the reading texts in the book rather than compiling the reading texts according to the themes and types of texts studied at certain meetings. From the results of the short interview, the researchers applied the potential of lokal wisdom in the learning process in the classroom, especially in presenting reading texts according to the themes studied. The development of this reading material begins with analyzing the potential of lokal wisdom.This study uses the Research and Development $(R \& D)$ method with reference to the Dick and Carey model with slight adjustments according to the research context. The learning steps include (1) identifying general learning objectives, (2) carrying out teaching analysis, (3) identifying input behavior and student characteristics, (4) formulating performance goals, (5) developing benchmark reference test items, (6) developing teaching strategies, (7) developing and selecting teaching materials, (8) designing and implementing formative evaluations, (9) revising learning materials, (10) designing and conducting summative evaluations.The results of the validation test of English reading materials based on lokal wisdom Ende-Lio by material experts, linguists and media experts were in the Good category with a score of $90 \%$.
\end{abstract}

Keywords: Development, Reading Materials, English, Lokal Culture, Ende-Lio

Copyright (c) 2022 Ningsih, Yuliana M.D'K.Kara

$\triangle$ Corresponding author

Email : ningsihverbhy@gmail.com

DOI : https://doi.org/10.31004/edukatif.v4i1.1719

ISSN 2656-8063 (Media Cetak)

ISSN 2656-8071 (Media Online)

Edukatif : Jurnal Ilmu Pendidikan Vol 4 No 1 Tahun 2022 p-ISSN 2656-8063 e-ISSN 2656-8071 


\section{PENDAHULUAN}

Kebudayaan adalah salah satu elemen yang sangat penting dalam proses pembelajaran. Keduanya tidak bisa dipisahkan satu sama lain. Aminullah, F.; Sada(2019) dalam penelitiannya mengatakan bahwa pembelajaran bahasa Inggris dan budaya harus diajarkan bersamaan. Hal ini agar siswa-siswi mengenal fungsi budaya mereka lewat pembelajaran bahasa Inggris. Dalam proses pembelajaran di sekolah, seorang guru harus memiliki kreativitas dan kemampuan dalam memadukan budaya lokal sehingga dapat memberikan semangat dan motivasi bagi siswa di kelas. Salah satu kreativitas atau kemampuan berinovasi adalah perangkat pembelajaran yang perlu dipersiapkan oleh guru adalah bahan ajar. Syaiful (Tri Kurniawati, Citra Kusumaningsih, 2015), mendefenisikan bahan ajar adalah segala bentuk bahan yang digunakan untuk membantu guru/instruktur dalam melaksanakan kegiatan belajar mengajar di kelas. Bahan ajar yang dibuat harus berdasarkan kebutuhan siswa.

Berdasarkan wawancara singkat peneliti dengan beberapa siswa bahwa mereka masih mengalami kesulitan dalam memahami isi bacaan pada teks bahasa Inggris. Hal ini disebabkan oleh beberapa faktor.seperti, kurangnya kreativitas guru dalam mengembangkan bahan ajar, bahan ajar yang digunakan guru temanya cukup luas, sehingga siswa-siswi sulit untuk memehami tema bacaan tersebut. Selain itu, mereka belum pernah belajar Bahasa Inggris di bangku Sekolah Dasar (SD). Demikian juga wawancara singkat dengan guru, dimana guru masih menggunakan teks bacaan yang ada di dalam buku daripada menyusun sendiri teks bacaan sesuai dengan tema dan jenis teks yang dipelajari pada pertemuan tertentu. Hal ini dapat disimpulkan bahwa guru belum kreatif membuat bahan ajar yang menerapkan potensi kearifan lokal dalam proses pembelajaran di kelas, terutama dalam penyajian teks bacaan sesuai dengan tema yang dipelajari. Sehingga siswa-siswi SMPS Rewarangga sulit memahami teks bacaan bahasa inggrisd engan baik.

Ningsih, (2021) menjelaskan bahasa Inggris merupakan salah satu bahasa penting yang harus dikuasai oleh masyarakat Indonesia karena bahasa Inggris memiliki kedudukan yang sangat strategis, yaitu selain sebagai alat komunikasi dan pergaulan bahasa antar manusia. Bahasa Inggris juga merupakan bahasa asing pertama yang dianggap penting untuk tujuan akses informasi, penyerapan, dan pengembangan ilmu pengetahuan, teknologi, dan seni budaya. Dalam kaitannya dengan bahasa asing, demikian halnya bahasa sasaran yang sedang dipelajari dan ingin dikuasai.Bentuk bahasa sasaran dapat berupa bahasa ibu bahasa pertama (L1), bahasa kedua (L2), atau bahasa asing (FL).

Sukarismanti \& Samsudin (2021) dalam penelitiannya mengatakan bahwa bahan ajar merupakan salah satu komponen sistem pembelajaran yang mempunyai peranan sangat penting dalam membantu siswa mencapai standar kompetensi dan kompetensi dasar.Selain itu juga, keterbatasan referensi pada mata kuliah antropolinguistik yang menyajikan nilai-nilai kearifan lokal menyebabkan lemahnya pemahaman mahasiswa akan nilai-nilai budaya daerah. Oleh karena itu, perlu mengintergasikan kearifan lokal dalam materi ajar antropolinguistik sebagai upaya penguatan pemahaman dan karakter mahasiswa program studi sastra IISBUD SAREA.Bahan ajar sangat penting pada saat pembelajaran dilakukan. Dengan bahan ajar dapat membantu siswa dan guru lebih mudah dalam proses pembelajaran. Namun sebagian besar ditemukan disekolah-sekolah bahan ajar yang digunakan oleh guru dan siswa kurang bervariatif. Pentingnya kreativitas guru membuat siswa-siswi termotivasi belajar bahasa Inggris, mereka tidak mudah bosan dan fokus pada apa yang diajarkan oleh guru dan aktif dalam menerima pelajaran (Y. M. D. K. Kara et al., 2021). Oleh karena itu perlu adanya pengembangan bahan ajar, khususnya bahan ajar yang berbasis kearifan lokal.

Selain itu juga merupakan salah satu bentuk upaya untuk melestarikan kearifan lokal adalah dengan cara memadukan nilai-nilai kearifan lokal kedalam proses pembelajaran. Dengan memadukan kearifan lokal dalam proses pembelajaran bahasa inggris siswa dapat memahami sebuah bacaan bahasa inggris dengan baik.Dengan demikian, siswa dapat memahami bahasa inggris dengan tidak menghilangkan identitas lokal itu sendiri (Untailawan \& Tuasela, 2020). Kearifan lokal adalah pengetahuan dasar dan pengelaman nyata yang 
terintegrasi dalam tubuh, lingkungan, yang diperoleh dalam kehidupan sehari-hari.Hal ini sesuai dengan penelitian yang dilakukan oleh Sariyyah (2021) penggunaan media belajar berbasis kearifan lokal terbukti meningkatkan kualitas hasil maupun proses belajar. Fitriani(2019) menambahkan bahwa dengan memadukan kearifan lokan dalam pembelajaran bahasa inggris dapat memperkenalkan budaya lokal kepada orang lain, diseluruh Indonesia. Tujuan diajarkan kearifan lokal pada peserta didik agar siswa-siswi dapat mengenal lebih jauh atau lebih akrab dengan lingkungan alam social dan budaya setempat. Selain itu memiliki bekal kemampuan dan dan ketrampilan serta pengetahuan tentang daerahnya sendiri dan berperilaku selaras dengan nilai-nilai yang berlaku di daerahnya serta mengembangkan nilai-nilai tersebut. Kearifan lokal yang ditawarkan dalam penelitian ini adalah kearifan lokal daerah Ende Lio. Bentuk kearifan lokal yang ada di Ende Lio seperti, rumah adat, ritual adat, makanan lokal, tempat wisata, dan pakaian adat Ende Lio.

Siregar (2021) dalam penelitiannya mengatakan bahwa ketika melihat kegiatan belajar sastra di beberapa kelas, sebagian besar guru hanya mengandalkan buku saja, misalnya buku paket, LKS, dan sebagainya. Dalam menyampaikan materi, guru hanya ceramah tanpa ada media yang dirancang. Oleh karena itu mengembangkan bahan ajar merupakan salah satu komponen sistem pembelajaran yang mempunyai peranan penting dalam membantu siswa mencapai standar kompetensi dan kompetensi dasar.

Penelitian terdahulu oleh Divan (2018) mengembangkan bahan ajar tematik menggunakan model Dick dan Carey. Langkah-langkah model pengembangan ini dilakukan sampai pada langkah ke 9, yaitu merevisi bahan pembelajaran. Langkah 10 ditiadakan karena dalam penelitian hanya diperoleh prototipe produk saja, sesuai dengan tujuan penelitian dan pengembangan. Berdasarkan hasil uji coba tersebut, bahan ajar tematik sangat valid, sangat menarik, efektif dan dapat diterapkan dalam pembelajaran. Hal ini dapat diketahui dari hasil uji validasi dari ahli materi sebesar 93,84\% ahli desain sebesar 94,19\% dan ahli bahasa sebesar 67,14\%. Tingkat kemenarikan produk dengan skor rata-rata sebesar 90,41\% masuk dalam kriteria sangat menarik. Produk efektif digunakan dengan rata-rata sebesar $90 \%$ masuk dalam kriteria sangat efektif. Dan keterterapan produk sangat menarik dengan rata-rata sebesar $93,00 \%$.

Penelitian ini juga menggunakan Model Dick dan Carrey yang memiliki 10 langkah pembelajaran yang sistematis, dari mengidentifikasi tujuan umum pembelajaran sampai melaksanakan evaluasi. Model pengembangan Dick and Craey dianggap cocok digunakan dalam kurikulum pendidikan dari tingkat dasar hingga perguruan tinggi.

Membaca adalah salah satu ketrampilan bahasa yang sangat penting selain keterampilan menulis, berbicara dan juga ketrampilan mendengarkan. Membaca dan memahami sebuah bacaan sangat sulit dilakukan oleh siswa-siswi SMPS Rewarangga, khususnya membaca teks bahasa inggris. Salah satu tujuan membaca adalah memberikan informasi atau pengetahuan tentang apa yang dibaca dengan menjawab pertanyaan yang diberikan oleh guru. Membaca adalah memperoleh informasi berupa tulisan yang membutuhkan pemahaman (Y. Kara \& Liru, 2021); (Dafit \& Mustika, 2021)

Membaca perlu ditekankan kepada setiap individu sejak kecil. Karena, informasi yang paling mudah untuk kita peroleh adalah melalui bacaan, baik koran, majalah tabloid, buku-buku, dan lain-lain. Minimnya budaya membaca di kalangan remaja Indonesia sangat perlu diperhatikan. Problema tersebut, tidak boleh di anggap remeh, karena besarnya rasa cinta membaca sama dengan kemajuan. Artinya, suatu tingkatan minat baca seseorang menentukan tingkat kualitas serta wawasannya.Kebiasaan membaca san gatperlu ditingkatkan terutama kepada para remaja Indonesia. Dalam proses belajar mengajar, mustahil berhasil tanpa adanya "membaca" (Pentingnya-Membaca @ Www.Kompasiana.Com,n.d.)

Nadlir (2014) dalam tulisannya memandang pendidikan berbasis kearifan lokal adalah pendidikan yang mengajarkan siswa untuk selalu lekat dengan situasi konkret yang mereka hadapi. Oleh karena itu kurikulum yang dipersiapkan adalah kurikulum yang sesuai dengan kondisi lingkungan hidup, minat, dan kondisi psikis siswa. Lebih lanjut Nadlir menyatakan model pendidikan berbasis kearifan lokal adalah contoh pendidikan 
yang memiliki hubugan yang cukup tinggi dengan kecakapan pengembangan hidup yang berdasrkan pada pemberdayaan keterampilan serta potensi-potensi lokal tiap daerah.

Namun kenyataanya bahwa kemampuan memahami bacaan yang diharapkan pada siswa belum terklihat pada siswa SMPS Rewarangga. Informasi yang diperoleh dari guru bahwa siswa sangat kesulitan memahami dan berpikir bacaaan bahasa Inggris. Hal ini terlihat ketika diberikan pertanyaan tentang teks bacaan yang telah dibaca. Mereka tidak mampu berpikir dan menjawab pertanyaan dengan baik.

Dilihat dari permasalahan di atas, siswa mengalami kesulitan dalam memahami bacaan, maka dari itu penulis berupaya mengahadirkan sebuah alternatif yang merupakan sangat efektif dalam mengatasi hal tersebut, dengan mencoba mengembangkan bahan bacaan berbasis budaya lokal, kelebihan bahan bacaan ini adalah menarik dan mudah dipahami, karena berhubungan langsung dengan lingkungan sosial, budaya dan lingkungan setempat.

Berdasarkan uraian diatas maka tujuan penelitian ini adalah untuk mengetahui prototype materi bacaan berbasis kearifan lokal Ende-Lio.

\section{METODE PENELITIAN}

Penelitian ini menggunakan metode Research and Development (R\&D). Metode penelitian dan pengembangan adalah metode penelitian yang digunakan untuk menghasilkan produk tertentu dan menguji keefektifan produk tersebut (Sugiyono, 2009). Metode penelitian ini merujuk pada model Dick and Carey dengan sedikit penyesuaian sesuai konteks penelitian. Adapun langkah-langkah pembelajarannya mencakup (1) mengidentifikasi tujuan umum pembelajaran, (2) melaksanakan analisis pengajaran, (3) mengidentifikasi tingkah laku masukan dan karakteristik siswa, (4) merumuskan tujuan performansi, (5) mengembangkan butirbutir tes acuan patokan, (6) mengembangkan strategi pengajaran, (7) mengembangkan dan memilih material pengajaran, (8) mendesain dan melaksanakan evaluasi formatif, (9) merevisi bahan pembelajaran, (10) mendesain dan melakukan evaluasi sumatif (Aji, 2016). Bagan berikut menunjukkan visualisasi dari langkahlangkah yang telah dideskripsikan di atas.

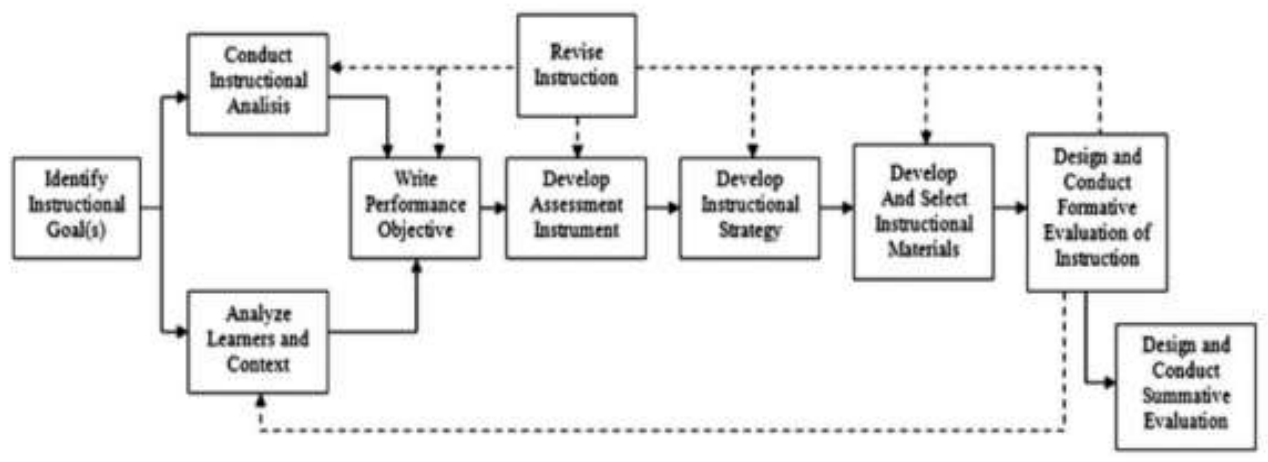

Bagan 1. Alur Model Pembelajaran Dick and Carrey

Lebih lanjut Aji menyatakan penggunaan model Dick and Carrey dalam pengembangan suatu mata pelajaran dimaksudkan agar: (a) pada awal proses pembelajaran, anak didik atau siswa dapat mengetahui dan mampu melakukan halhal yang berkaitan dengan materi pada akhir pembelajaran, (b) adanya pertautan antara tiap komponen, khususnya strategi pembelajaran dan hasil pembelajaran yang dikehendaki, (c) menerapkan langkah-langah yang perlu dilakukan dalam melakukan perencanaan desain pembelajaran.

Penelitian dilaksanakan di Kabupaten Ende, Propinsi Nusa Tenggagra Timur, pada bulan Januari sampai dengan bulan November 2021. Subjek dalam penelitian ini adalah guru, dan siswa untuk di uji coba prototype teks bacaan bahasa Inggris berbasis budaya lokal Ende-Lio bagi siswa kelas VII SMP. Sampel 
sumber data yang dipilih secara purposive yakni n yang memiliki kompetensi sesuai dengan kebutuhan data. Penelitian ini dilakukan dalam tiga tahap kegiatan yaitu, tahap analisis potensi-potensi kearifan lokal daerah Ende-Lio, tahap pengembangan teks bacaan bahasa Inggris, dan tahap implementasi untuk mengetahui keefektifan penggunaan teks bacaan bahasa Inggris berbasis budaya lokal Ende-Lio bagi siswa kelas VII SMP.

Prosedur penelitian dilakukan melalui dua tahap yakni dengan menganalisis potensi-potensi kearifan lokal budaya Ende-Lio. Untuk memperoleh data mengenai potensi-potensi kearifan lokal budaya Ende-Lio ini, peneliti menggunakan beberapa tahap berikut ini.

a. Metode wawancara: wawancara pada narasumber dilakukan dengan menggunakan pedoman wawancara

b. Metode dokumentasi: dalam penelitian ini, dokumentasi diperoleh dari hasil penyelidikan yang dimuat dalam bentuk artikel hasil penelitian dan buku tentang kebudaayn daerah Ende-Lio

Instrumen penelitian yang digunakan dalam penelitian ini antara lain untuk analisis potensi kearifan lokal yang digunakan adalah panduan wawancara dan dokumentasi. Dan untuk pengembangan teks bacaan bahasa Inggris berbasis budaya lokal Ende-Lio, penilaian berdasarkan acuan kelayakan yang meliputi kelayakan komponen isi, komponen kebahasan, dan komponen penyajian, dengan menggunakan lembar validasi oleh ahli yang berkompeten. Teknik dalam pengumpulan data antara lain dengan menggunakan adalah metode wawancara dan dokumentasi. Pengembangan teks bacaan bahasa Inggris berbasis budaya lokal Ende-Lio menggunakan validasi ahli oleh ahli yang berkompeten dibidangnya dengan menggunakan lembar validasi. Teknik analisis data untuk menganalisis potensi-potensi kearifan lokal menggunakan langkahlangkah sebagai berikut; a. Pengumpulan data; b. Reduksi data; dan c. Display data; Verifikasi dan penegasan kesimpulan; Analisis kelayakan bahan ajar dilakukan dengan deskriptif kualitatif.

\section{HASIL DAN PEMBAHASAN PENELITIAN}

\section{Hasil Penelitian}

\section{Potensi Kearifan Lokal Ende-Lio}

Beragam kearifan lokal yang ada di masyarakat tidak saja menjadi kebiasaan dan adat istiadat. Kearifan lokal bahkan telah menjadi budaya masyarakat (Rajafi, 2016). Kabupaten Ende merupakan sala satu wilayah yang ada di Nusa Tenggara Timur. Etnik besar yang ada di Kabupaten Ende adalah etnik Lio dan etnik Ende, dengan berbagai macam suku di dalamnya. Pelaksanaan penelitian ini dilakukan dengan mengacu pada rumusan masalah yakni untuk mengetahui prototype bahan bacaan bahasa Inggris berbasis kearifan lokal Ende-Lio.

Masyarakat Ende-Lio menyimpan beragam kebudayaan atau pun adat istiadat yang menjadi kearifan lokal masyarakat setempat (Jehamat, L., Mbadhi, 2018). Berdasarkan wawancara yang dilakukan tim peneliti dengan tokoh masyarakat, dan guru mata pelajaran bahasa Inggris diketahui beberapa potensi kearifan lokal Ende-Lio. Berikut potensi kearifan lokal yang terdapat pada di masyarakat Ende-Lio, yakni:

a. Makanan Lokal

Makanan lokal masyarakat Ende-Lio antara lain Wa'I Punga yakni olahan singkong yang diparut, lalu dicincang. Setelah dicincang singkong kemudian di rebus hingga matang. Biasanya, Wa'I Punga ditemani dengan lauk ikan kuah santan atau bisa juga dengan sambal ikan.

b. Ritual Adat

Ritual adat yang terdapat di masyrakat Ende-Lio antara lain ritual Taga Kamba, merupakan acara penyembelihan hewan kerbau sebagai tanda rapat koordinasi tiga unsur batu tungku, yaitu tokoh adat, pemerintah dan tokoh agama sebagai satu kesatuan dalam menjalankan pembangunan di Kabupaten Ende. 
294 Pengembangan Bahan Bacaan Bahasa Inggris Berbasis Budaya Lokal Ende-Lio untuk Siswa Sekolah Menengah Pertama - Ningsih, Yuliana M.D'K.Kara

DOI: https://doi.org/10.31004/edukatif.v4i1.1719

c. Rumah adat

Rumah Mosalaki merupakan tempat tinggal khas Suku Ende Lio. Nama Mosalaki diambil dari kata Mosa yang berarti ketua dan Laki yang berarti adat.

d. Tempat Wisata

Tempat wisata yang paling terkenal di Ende-Lio yakni Danau Tiga warna Kelimutu, di Kecamatan Kelimutu, Moni. Dalam bahasa daerah Ende-Lio dikenal dengan nama Kelimutu Tiwu Telu. Danau ini terkenal karena keindahan warna dari ketiga kawahnya yang berbeda-beda dan bahkan sewaktu-waktu dapat berubah warna.

e. Pakaian Adat

Terkait pakaian adat daerah Ende-Lio terbagi menjadi 2 yakni pakaian adat untuk kaum pria yang terdiri atas ragi/luka, yakni sarung hitam dari hasil tenunan dan bagi para mosalaki atau tua adat juga mengenakan semba, yakni selendang yang dipakai di salah satu bahu secara simestris, serta lesu atau destar yang dipakai pada kepala. Sedangkan bagi kaum wanita dipakai lawo dan lambu yakni sarung tenunan dan baju berukuran lebar seperti baju bodo. Pakaian adat ini biasanya dipakai pada saat acara-acara adat atau acara tertentu dan dipakai sehari-hari.

Dari potensi kearifan lokal yang ditemukan, serta dilengkapi dengan hasil wawancara peneliti dengan guru, peneliti kemudian mulai mengembangkan materi bacaan Bahasa Inggris berbasis Kearifan Lokal budaya Ende-Lio dalam bentuk modul. Berikut produk yang dikembangkan oleh peneliti;

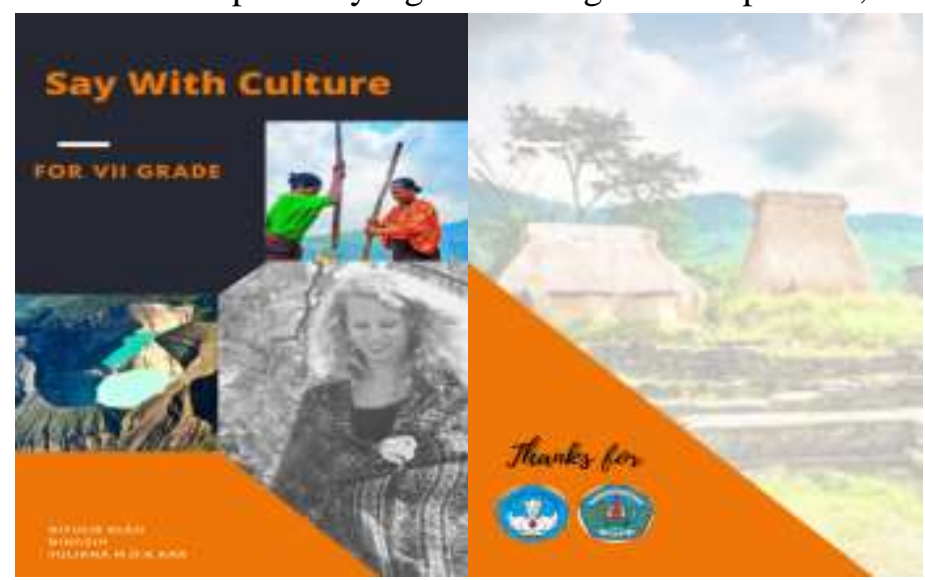

\section{Gambar 1. Sampul Modul Bahan Bacaan Bahasa Inggris Berbasis Kearifan Lokal Ende-Lio}

Berdasarkan potensi kearifan lokal dan wawancara dengan guru mata pelajaran bahasa Inggris terkait sumber buku dan materi yang diajarkan maka peneliti merumuskan kompetensi inti, kompetensi dasar, dan materi ajar.



Gambar 2. Materi Ajar Pada Modul Bahan Bacaan Bahasa Inggris Berbasis Kearifan Lokal Ende-Lio 
Setelah dikembangkan, bahan bacaan tersebut divalidasi oleh para vaildator untuk melihat validitasnya.Berdasarkan hasil validasi dari kedua validator yakni pada validator ahli materi dan ahli grafis, serta dari kesimpulan yang diperoleh dari para validator bahwa bahan bacaan yang telah dikembangkan dapat di uji cobakan dengan beberapa hal yang harus direvisi.

\section{Pembahasan}

Setelah dikembangkan, bahan bacaan tersebut divalidasi oleh para vaildator untuk melihat validitasnya. Berdasarkan hasil validasi dari kedua validator yakni pada validator ahli materi dan ahli grafis, serta dari kesimpulan yang diperoleh dari para validator bahwa bahan bacaan yang telah dikembangkan dapat di uji cobakan dengan beberapa hal yang harus direvisi. Seperti halnya penelitian yang dilakukan oleh Samsudin \& Sukarismanti (2021), produk yang dikembangkan adalah bahan ajar berbasis tugas dan kearifan lokal untuk pembelajaran bahasa Inggris mahasiswa Iisbud Sarea dimasa pandemi. Kemudian, metode penelitian ini menggunakan model pengembangan ADDIE yaitu analysis, design, development, implementation, and evaluation. Hasil penelitian menunjukkan bahwa hasil uji validasi ahli materi, ahli bahasa dan media terhadap modul yang dikembangkan berada pada kategori "tinggi" dan "sangat tinggi". Kemudian, hasil uji kepraktisan baik dari segi mahasiswa maupun dosen pengampuh bahwa modul berada pada kategori "praktis" dan "sangat praktis"

Dalam kaitannya dengan bahasa asing, Nova Mustika (2019) mengemukakan adanya istilah bahasa target yang merupakan bahasa yang sedang dipelajari dan ingin dikuasai. Wujud bahasa target dapat berupa bahasa ibu (bahasa pertama (B1), bahasa kedua (B2), maupun bahasa asing (BA). Pengertian bahasa kedua tidak sama dengan bahasa bahasa asing. Di Indonesia misalnya, pertama kali pembelajar belajar bahasa pertama (bahasa daerah), kemudian belajar bahasa kedua (Bahasa Indonesia).

Hasil uji validasi produk bahan bacaan bahasa Inggris berbasis kearifan lokal Ende-Lio yang di berikan pada ahli materi, ahli bahasa dan media di peroleh kategori Baik dengan beberapa catatan, antara lain oleh ahli materi bahwa dalam bahan bacaan yang di nilai, masih perlu penambahan pada aspek budaya Ende-Lio. Sedangkan oleh ahli bahasa dan media diperoleh catatan bahwa bahan bacaan yang dikembangkan perlu diperbaiki kembali grammarnya karena masih ditemukan beberapa bacaan yang terdapat kekeliruan pada grammarnya.Namun, pada kesimpulannya diperoleh bahwa produk bahan bacaan bahasa Inggris berbasis kearifan lokal Ende-Lio yang telah dikembaghkan dapat digunakan dengan sedikit revisi.

Berdasarkan hasil uji validasi, ditemukan bahwa penelitian yang dilakukan oleh Sandiyasa et al., (2013) memiliki kemiripan yang bertujuan untuk mengembangkan materi pembelajaran yang menyatu-padukan membaca dan menulis yang berbasis ICT untuk siswa kelas 7 di SMP N 4 Baturiti. Penelitian ini dirancang ber- dasarkan pada rancangan penelitian pengembangan yang dikemukakan oleh Dick, Carey dan Carey di tahun 2005. Model penelitian ini terdiri atas tiga langkah utama yaitu; analisa keperluan, pengembangan produk, dan evaluasi produk. Analisa keperluan diadakan dalam rangka memperoleh informasi tentang apa yang diperlukan dan sifat khas siswa, infrastruktur sekolah, dan topik yang harus muncul di dalam produk. Pada langkah pengembangan produk, materi dikumpulkan dan kemudian dikembangkan dengan menggunakan dua program bernama Hot Potatoes dan Macromedia Dreamweaver. Pada langkah evaluasi produk, diadakan penilaian ahli dan pengujian lapangan (field try-out) terhadap produk tersebut. Untuk keperluan langkah penilaian dari ahli, penelitian melibatkan dua ahli yang masing - masing memiliki keahlian dalam bidang berbeda yaitu; isi/ kurikulum dan ICT. Hasil penilaian ahli menunjukkan kualitas materi yang dikembangkan sangat baik dengan nilai 3,88 dalam skala $0.1-4.0$.

Selain itu, terkait dengan pengujian lapangan terhadap produk juga diadakan untuk menguji apakah materi yang dikembangkan tersebut bisa dipakai dengan baik untuk mengajar keterampilan membaca dan menulis. Hasil pengujian menunjukkan bahwa materi tersebut dapat dipergunakan dimana ini bisa dilihat dari tanggapan positif yang diberikan siswa sebanyak $86 \%$. Hal ini berbeda dengan penelitian yang dilakukan oleh 
296 Pengembangan Bahan Bacaan Bahasa Inggris Berbasis Budaya Lokal Ende-Lio untuk Siswa Sekolah Menengah Pertama - Ningsih, Yuliana M.D'K.Kara

DOI: https://doi.org/10.31004/edukatif.v4i1.1719

penelti dan tim karena dengan keterbatasan waktu belum melakukan uji coba produk di lapangan, sehingga dalam penelitian ini peneliti memfokuskan pada penilaian produk oleh para ahli materi, ahli media, dan grafis, dengan capaian nilai layak untuk diterapkan pada kelas VII SMP.

\section{KESIMPULAN}

Prototipe bahan bacaan Bahasa Inggris berbasis kearifan lokal Ende-Lio yang dikembangkan adalah dalam bentuk modul. Penilaian dilakukan oleh du orang ahli yakni ahli materi dan ahli bahasa serta media. Berdasarkan analisis pada instrumen penilaian oleh ahli materi bahwa dalam bahan bacaan yang di nilai, masih perlu penambahan pada aspek budaya Ende-Lio. Sedangkan oleh ahli bahasa dan media diperoleh catatan bahwa bahan bacaan yang dikembangkan perlu diperbaiki kembali grammarnya karena masih ditemukan beberapa bacaan yang terdapat kekeliruan pada grammarnya. Namun, pada kesimpulannya diperoleh bahwa produk bahan bacaan bahasa inggris berbasis kearifan lokal Ende-Lio yang telah dikembangkan dapat digunakan dengan sedikit revisi.

\section{UCAPAN TERIMA KASIH}

Terima kasih peneliti ucapkan kepada pihak PDDIKTI dan Universitas Flores yang telah mempercayakan peneliti untuk melaksanakan kegiatan Penelitian Dosen Pemula (PDP).

\section{DAFTAR PUSTAKA}

Aji, W. N. (2016). Model Pembelajaran Dick And Carrey Dalam Pembelajaran Bahasa Dan Sastra Indonesia. Kajian Linguistik Dan Sastra, 1(2), 119. Https://Doi.Org/10.23917/Kls.V1i2.3631

Aminullah, F.; Sada, C. . S. (2019). Lokal Culture-Based Reading Materials For Efl Context. Fajar Aminullah, Clarry Sada, Sudarsono Sudarsono, 2(2), 193-197.

Dafit, F., \& Mustika, D. (2021). Pengembangan Bahan Ajar Membaca Berbasis Higher Order Thinking Skills Pada Siswa Sekolah Dasar. Edukatif: Jurnal Ilmu Pendidikan, 3(6), 4889-4903. Https://Www.Edukatif.Org/Index.Php/Edukatif/Article/View/1565

Divan, S. (2018). Pengembangan Bahan Ajar Tematik Berbasis Budaya Lokal Untuk Siswa Kelas Iv Sekolah Dasar. Ilmu Pendidikan: Jurnal Kajian Teori Dan Praktik Kependidikan, 3(1), 101-114. Https://Doi.Org/10.17977/Um027v3i12018p101

Fitriani, Y. (2019). Developing A Guideline Of English Teaching Materials Based On Lokal Culture For Vii Graders In Paser Regency East Kalimantan. Inovish Journal, 4(2), 141-152.

Jehamat, L., Mbadhi, A. C. (2018). Aewora , Kecamatan Maurole, Kabupaten Ende The Role Of Tura Jaji Culture Prevents Social Conflict In Aewora Village , Maurole District, Ende Regency Lasarus Jehamat Aprilia Clarisa Mbadhi Abstrak Kearifan Lokal Berperan Penting Dalam Menjaga Solidaritas. Sosio Informa, 4(3), 567-580.

Kara, Y., \& Liru, M. W. (2021). Pengaruh Strategi Pembelajaran Mind Mapping Dan Rasa Percaya Diri Terhadap Kemampuan Berbicara Bahasa Inggris. Edukatif: Jurnal Ilmu Pendidikan, 3(6), 4980-4986. Https://Www.Edukatif.Org/Index.Php/Edukatif/Article/View/1600

Kara, Y. M. D. K., Doi, M., \& Flores, U. (2021). Pengaruh Strategi Pembelajaran Inovatif Directed Reading And Thinking Activity ( Drta ) Dan Motivasi Belajar Terhadap Kemampuan Membaca Bahasa Inggris Siswa. 4(1), 59-68. Https://Journal-Litbang-Rekarta.Co.Id/Index.Php/Jartika

Ningsih. (2021). Edukatif: Jurnal Ilmu Pendidikan Developing English Teaching And Learning Materials For Mathematics Study Program. 3(4), 1112-1119. 
297 Pengembangan Bahan Bacaan Bahasa Inggris Berbasis Budaya Lokal Ende-Lio untuk Siswa Sekolah Menengah Pertama - Ningsih, Yuliana M.D'K.Kara

DOI: https://doi.org/10.31004/edukatif.v4i1.1719

Nova Mustika, Dan A. S. (2019). Pengembangan Modul English In Analyzer Dalam Peningkatan Kemampuan Berbahasa I. Jurnal Ilmu Pendidikan, 1(3), 107-112. Https://Edukatif.Org/Index.Php/Edukatif/Index

Pentingnya-Membaca @ Www.Kompasiana.Com. Https://Www.Kompasiana.Com/121199/5a9bfdd6f1334407d31b9e64/Pentingnya-Membaca

(N.D.).

Rajafi, A. (2016). Resolusi Konflik Keluarga Berbasis Lokal Wisdom(Reaktualisasi Filosofi Masyarakat Sulawesi Utara Torang Samua Basudara). Yudisia, 7(1), 1-16.

Samsudin, S., \& Sukarismanti, S. (2021). Development Of Assignment-Based Teaching Materials And Lokal Wisdom For English Learning Of Iisbud Sarea Students During The Pandemic. Edukatif: Jurnal Ilmu Pendidikan, 3(6), 3786-3793. Https://Edukatif.Org/Index.Php/Edukatif/Article/View/1107

Sandiyasa, I. W., Putra, I. N. A. J., \& Budasi, I. G. (2013). Developing Ict Based Integrated Reading And Writing Materials For The Seventh Grade Students Of Smpn 4 Baturiti In The Academic Year 2012 / 2013.

Sariyyah, N. (2021). Media Tenun Ikat Ende-Lio Untuk Meningkatkan Kualitas Belajar Siswa Di Sekolah Dasar. Edukatif: Jurnal Ilmu Pendidikan, 3(5), 2105-2113. Https://Www.Edukatif.Org/Index.Php/Edukatif/Article/View/759

Siregar, J. (2021). Edukatif: Jurnal Ilmu Pendidikan Pengembangan Bahan Ajar Membaca Sastra Berbasis Pendekatan Kontekstual Pada Siswa Smp. 3(6), 4274-4288.

Sugiyono. (2009). Metode Penelitian Kuantitatif, Kualitatif Dan R\&D. Bandung, Alfabeta.

Sukarismanti, \& Samsudin. (2021). Edukatif : Jurnal Ilmu Pendidikan Integrasi Kearifan Lokal Dalam Bahan Ajar Antropolinguistik Sebagai Upaya Penguatan Pemahaman Dan Karakter Mahasiswa. Edukatif: Jurnal Ilmu Pendidikan, 3(5), 3339-3349.

Tri Kurniawati1, Citra Kusumaningsih2, Y. R. E. (2015). Pengembangan Draft Bahan Ajar Pada Mata Kuliah Basic Reading Program Studi Bahasa Inggris. Jurnal Pendidikan Bahasa, 4(2), 281-293.

Untailawan, F., \& Tuasela, P. E. (2020). Media Pembelajaran Berbasis Kearifan Lokal Untuk Mengajar Bahasa Inggris: Menjaga Identitas Lokal Dan Nasional Dalam Moderenisasi Global. Researchgate, June, 3 . 